\title{
EVALUASI AGRIBISNIS STROBERI ORGANIK DI KABUPATEN BOLAANG MONGONDOW TIMUR PROVINSI SULAWESI UTARA
}

\author{
Agnes Estephina Loho \\ Jen Tatuh \\ Gene H. M. Kapantow
}

\begin{abstract}
The purpose of this study was to evaluate organic strawberry agribusiness in the East Bolaang Mongondow Regency by evaluating the dimensions of agribusiness players, the dimensions of agribusiness activity and the dimensions of behavior of organic strawberry agribusiness. The method used in this study was the survey method. The selection of the location of the study was done intentionally by determining the highland area in the East Bolaang Regency that cultivated strawberries. The area was the village of Mooat, Guaan Village, and New Bongkudai Village. This research begins in May to August 2018. The types of data used in this study were primary and secondary data. Data were analyzed using income analysis, added value, and were evaluated with an evaluation structure design adopted from the modified Hammond Evaluation Structure into agribusiness. The results of the study showed that agribusiness players consisting of key players had not made strawberries as commercial commodities while the tourism business of D'Mooat had made strawberries as a commercial commodity. The agricultural input activities were in the form of the use of the workforce of the community around the tourist area and the provision of production facilities, both purchased and made by themselves. The agricultural production activities had not fully utilized organic materials with an average production of 1,080 $\mathrm{kg} /$ year and the revenues of Rp.128,505,250/year for the area of 2,000 $\mathrm{m2}$. The agricultural industry activities provided added value around of $R p .57,000 / \mathrm{kg}$ for strawberries and the average profit of Rp. 52,870/ $\mathrm{kg}$ through processing strawberries into strawberry juice, smoothie strawberry juice and dragon berry juice. Agricultural marketing activities were take place only in the tourist attractions area. The agricultural service activities were in the form of credit from Bank (BRI) while coordination with related agencies has not been established. The production technique behavior was good; the agribusiness management behavior was still in traditional way, whereas the agribusiness system behavior have not opptimally yet.
\end{abstract}

Keywords: organic agriculture, organic strawberries, agribusiness, Hammond evaluation structure

Tujuan dari penelitian ini adalah untuk mengevaluasi agribisnis stroberi organik di Kabupaten Bolaang Mongondow Timur dengan mengevaluasi dimensi pelaku agribisnis, dimensi aktivitas agribisnis dan dimensi perilaku agribisnis stroberi organik. Metode yang digunakan dalam penelitian ini adalah metode survei. Pemilihan lokasi penelitian dilakukan secara sengaja yaitu di daerah dataran tinggi di Kabupaten Bolaang Timur yang membudidayakan stroberi yang meliputi tiga desa yaitu Desa Mooat, Desa Guaan, dan Desa Bongkudai Baru. Penelitian ini dimulai pada bulan Mei hingga Agustus 2018. Jenis data yang digunakan dalam penelitian ini adalah data primer dan sekunder. Data dianalisis menggunakan analisis pendapatan, nilai tambah, dan dievaluasi dengan desain struktur evaluasi yang diadopsi dari Struktur Evaluasi Hammond yang dimodifikasi menjadi agribisnis. Hasil penelitian menunjukkan bahwa pelaku agribisnis yang terdiri dari pelaku kunci tidak menjadikan stroberi sebagai komoditas komersial, sementara bisnis pariwisata D’Mooat telah menjadikan stroberi sebagai komoditas komersial. Aktivitas agriinput adalah dalam bentuk penggunaan tenaga kerja masyarakat di sekitar kawasan wisata dan penyediaan fasilitas produksi, baik yang dibeli dan dibuat sendiri. Aktivitas agroproduksi pertanian belum sepenuhnya memanfaatkan bahan organik dengan produksi rata-rata $1.080 \mathrm{~kg} /$ tahun dan pendapatan Rp.128.505.250 / tahun untuk luas $2.000 \mathrm{~m} 2$. Aktivitas agroindustri memberikan nilai tambah untuk stroberi sekitar Rp. 57.000 / kg dan rata-rata keuntungan Rp. 52.870 / kg melalui pengolahan stroberi menjadi jus stroberi, jus smoothie stroberi dan jus buah naga. Aktivitas agriniaga hanya berlangsung di daerah tempat wisata. Aktivitas agriservis berupa kredit dari Bank (BRI) sedangkan koordinasi dengan instansi terkait belum terjalin. Perilaku teknik produksi sudah berjalan dengan baik, perilaku manajemen adalah managemen keluarga sehingga dapat dikatakan masih menggunakan cara tradisional, sedangkan perilaku sistem agribisnis belum berjalan optimal.

Kata kunci: pertanian organik, stroberi organik, agribisnis, Struktur evaluasi Hammond

Agrisosioekonomi:

Jurnal Transdisiplin Pertanian (Budidaya Tanaman, Perkebunan, Kehutanan, Peternakan, Perikanan), Sosial dan Ekonomi 


\section{PENDAHULUAN}

\section{Latar Belakang}

Berkembangnya kesadaran konsumen akan keamanan pangan dan kebutuhan makanan sehat, menuntut produsen dan petani untuk mengusahakan komoditas pertanian yang aman dan bebas dari penggunaan bahan-bahan kimia yang berbahaya. Sejalan dengan program Pemerintah untuk meningkatan pendapatan petani melalui penguatan pangan lokal yang bernilai ekonomi tinggi maka stroberi organik dapat menjadi pionir untuk dikembangkan. Budidaya stroberi di Kabupaten Bolaang Mongondow Timur sudah mulai pada tahun 2012.

Penggalakan usahatani yang berkelanjutan dengan memanfaatkan sumberdaya lokal untuk menghasilkan makan yang sehat yang sehat, mulai digalakan dengan dicanangkannya tahun organik pada tahun 2010. Pencanangan pertanian organik perlu terus didengungkan dan dilaksanakan untuk membangun pertanian yag berkelanjutan. Hasil penelitian Tangkulung dkk (2015) tentang prefernce konsumen terhadap sayuran organik ditinjau dari segi harga, kesegaran, ketersediaan, dan kemasan di Hypermart Manado menunjukkan tingkat kepuasan konsumen masuk dalam kategori puas.

Tanaman stroberi adalah buah yang sangat berkasiat bagi kesehatan dan bernilai ekonomi yang tinggi. Buah ini dapat dikonsumsi langsung sebagai buah segar, jus, ataupun penghias kue tart, dan dapat juga menjadi tanaman hias. Hasil penelitian di Kabupaten Purbalingga menunjukkan bahwa strategi pengembangan stoberi berupa peningkatkan permodalan, adopsi teknologi pengolahan hasil, penambahan pendidikan serta permodalan Purnomo (2008). Wuner dkk (2015) menunjukkan pendapatan ratarata petani stroberi $\mathrm{Rp} 2.679 .630$ perbulan dengan mengusahakan 1000 tanaman stroberi. Menurut Widyantara (2015), Di Desa Pancasari, Kabupaten Buleleng, tanaman stroberi seluas 100 meter persegi dapat ditanam 4000 tanaman stroberi dengan setiap kali panen mencapai $20 \mathrm{~kg}$ dan mampu memberikan keuntungan Rp 3 juta perbulan. Beberapa penelitian menunjukkan bahwa R/C dari tanaman stroberi bernilai 1,29 yang mengindikasikan bahwa usahatani stroberi menguntungkan (Rukmana, 1998).
Senewe dkk (2107) menunjukkan bahwa di Kelurahan Rurukan dan Rurukan Satu, agroekologi lokasi, ketersediaan bibit, pupuk, harga merupakan faktor pendukung usahatani, selanjutnya iklim yang ekstrim, lahan organik, merupakan kendala utama dalam pengembangan stroberi. Hal ini menyebabkan pada musim kemarau yang panjang pada 2015, tinggal 5 petani yang mengusahakan tanaman stroberi. Selanjutnya kelompok tani Agape yang merupakan pengembang tempat wisata bukit Temboan sudah mengusahakan tanaman ini sejak tahun 2008. Berdasarkan keterbatasan lahan, maka pengembangan selanjutnya dapat dilakukan halaman-halaman masyarakat untuk memenuhi pemintaan (Loho dan Kumaat, 2016). Pemasaran stroberi di kelurahan Rurukan mempunyai dua saluran pemasaran yaitu petani menjual sendiri di tempat wisata Puncak Temboan dan supermarket di Tomohon dan Mando dengan farmer share sebesar 53,73\% (Kodobik dkk,2017).

Ditinjau dari tingkat pendapatan stroberi dan preference konsumen terhadap komoditi pertanian organik, maka perlu diadakan evaluasi agribisnis stroberi organik di Kabupaten Bolaang Mongondow Timur.

\section{Perumusan Masalah}

Pertanian organik yang ramah lingkungan dan produk yang dihasilkan bebas residu kimia berbahaya merupakan suatu terobosan dalam menjawab tantangan pembangunan pertanian. Di pihak lain, masih rendahnya tingkat pendapat petani menjadi tantangan untuk peningkatan kesejahteraan petani demikian juga keamanan petani dan kesehatan konsumen menjadi perhatian. Oleh sebab itu diperlukan suatu rekomendasi untuk memberikan suatu wawasan kebijakan untuk mengembangkan agribisnis stroberi organik. Dalam rangka penysunan rekomendasi tersebut yang menjadi masalah dalam penelitian ini adalah:

1. Bagaimana pelaku agibisnis dan masingmasing subsistem agribisnis stroberi.

2. Bagaiman aktivitas agribisnis stroberi pada masing-masing subsistem berupa harga input faktor, pendapatan petani, nilai tambah.

3. Bagaimana perilaku agribisnis stroberi organik di Kabupaten Bolaang Mongondow Timur. 


\section{Manfaat Penelitian}

Manfaat dari penelitian ini adalah

1. Bagi peneliti, dapat dijadikan referensi dalam pembelajaran mata kuliah manajemen agribinis dan manajemen penyuluhan pertanian.

2. Bagi pembaca, dapat dijadikan sumber informasi untuk penelitian sejenis atau pengembangannya.

3. Bagi Pemerintah, dapat dijadikan bahan pertimbangan dalam pengembangan agribisnis stroberi organik.

4. Memberikan rekomendasi untuk peningkatan agribisnis stroberi organik di Bolang Mongondow Timur.

\section{Tujuan Penelitian}

Penelitian ini bertujuan untuk mengetahui:

1. Aktivitas dari pelaku agribisnis masingmasing subsistem agribisnis stroberi.

2. Usaha agribisnis pada masing-masing subsistem berupa harga input faktor, pendapatan petani, dan nilai tambah.

3. Perilaku agribisnis stroberi organik.

\section{METODE PENELITIAN}

\section{Lokasi dan Waktu Penelitian}

Penelitian ini dilakukan di Kabupaten Bolaang Mongondow Timur dengan mengambil daerah yang terletak di dataran tinggi yaitu desa Mooat, Desa Bongkudai Baru dan Desa Guaan. Penelitian ini dimulai pada bulan Mei sampai bulan Agustus 2018.

\section{Ruang Lingkup Penelitian}

Fokus dari evaluasi adalah pelaku agribisnis yaitu petani dan pengembang wisata D'Mooat yang membudidayakan stroberi dengan menitik beratkan pada aktivitas agribisnis stroberi pada masing-masing subsistem agribisnis dengan perilaku agribisnisnya.

\section{Teknik Pengumpulan Data}

Jenis data yang digunakan dalam penelitian ini adalah data primer dan data sekunder. Data primer diperoleh dari pelaku agribisnis sedangkan data sekunder diperoleh dari Kantor BPS, BAPEDA, dan Kantor Kelurahan. Metode pengumpulan data berupa:

a. Wawancara, untuk mengumpulkan data primer berdasarkan daftar pertanyaan yang telah disiapkan baik untuk subsistem agriinput, sub- sistem agriproduksi, subsistem agro-industri, subsistem agri-niaga, dan agri-servis.

b. Observasi, dilakukan dengan mengadakan pengamatan langsung terhadap pelaku agribisnis yang diteliti.

c. Dokumentasi berupa rekaman kegiatan yang diteliti maupun yang telah dilakukan dan pencatatan data sekunder dari instansi atau lembaga yang berhubungan dengan penelitian ini.

\section{Konsepsi Pengukuran Variabel}

Peubah yang digunakan dalam penelitian adalah peubah yang digunakan dalam menyusun model evaluasi berupa:

1) Dimensi Pelaku Agribisnis meliputi:

a. Pelaku petani

2) Dimensi Aktivitas Agribisnis meliputi:

a. Aktivitas subsistem agri-input meliputi ketersediaan dan kebutuhan input usahatani sebagai on-farm dan input agroindustri sebagai off-farm.

b. Aktivitas Agri-produksi meliputi aktivitas pengelolaan usahatani stroberi mulai penggunaan bibit hingga pemeliharaan, dan pendapatan petani.

c. Aktivitas Agro-industri meliputi transformasi produk dan nilai tambahnya.

d. Aktivitas Agri-niaga meliputi aktivitas pemasaran buah stroberi menurut pola saluran pemasaran.

e. aktivitas Agriservis berupa aktivitasaktivitas kelembagaan yang ada.

3) Dimensi Perilaku Agribisnis meliputi:

a. Dimensi perilaku teknik produksi meliputi teknik budidaya.

b. Dimensi perilaku manajemen agribisnis meliputi manajemen produksi, manajemen sumberdaya manusia, manajemen pemasaran, dan manajemen keuangan.

c. Dimensi perilaku hubungan subsistem agribisnis meliputi sinergitas antar subsistem agribisnis. 


\section{Analisis Data}

Data yang dikumpulkan ditabulasi dalam bentuk Tabel dan diinterpritasi secara deskriptif untuk kemudian dilakukan penarikan kesimpulan.

Analisis yang digunakan adalah: analisis kuantitatif berupa pendapatan petani, dan nilai tambah, (2) model evaluasi yang diadopsi dari model Struktur Evaluasi Hammond (1967), yang dirancang ke dalam aktivitas agribisnis. Dimensi institusi digantikan oleh daerah aktivitas pelaku agribisnis; Dimensi metode digantikan oleh dimensi aktivitas agribisnis, dan Dimensi Behavior digantikan oleh dimensi perilaku agribisnis.

Desain Model evaluasi pengembangan agribisnis stroberi dapat dilihat pada Gambar 1 .

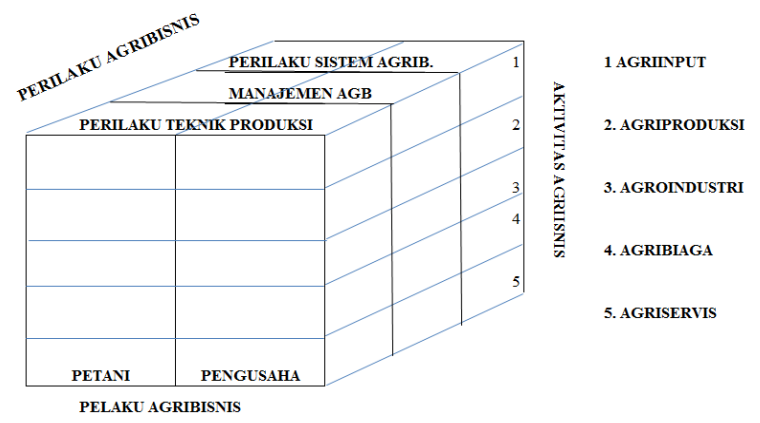

Gambar 1. Struktur Evaluasi agribisnis stroberi organik

\section{HASIL DAN PEMBAHASAN}

\section{Deskripsi Lokasi Penelitian}

Lokasi penelitian berada di dataran tinggi yaitu $1100 \mathrm{mdpl}$. Hasil pertanian di daerah ini adalah tanaman hortikultura berupa kentang, kubis, wortel, bawang, labu kuning. Mata pencaharian utama dari penduduk adalah petani.

\section{Persepsi Responden terhadap Pengembangan Stroberi Organik}

Pelaku utama petani dan pelaku usaha mempunyai persepsi yang berbeda dalam pengembangan stroberi organik. Persepsi petani terhadap strroberi organik adalah tanaman tanaman hias sehingga pembudidayaanya hanya di pekarangan rumah. Sebaliknya pelaku usaha yaitu pemilik tempat wisata D'Mooat melihat komoditi ini mempunyai nilai komersial yang tinggi. Oleh sebab itu pelaku usaha ini selalu mencari inovasi terbaik untuk pengembangannya. Pembudidayannya sudah menggunakan bahan-bahan organik sebagai pupuk maupun pestida, namun masih juga menggunakan pupuk dan pestida anorganik/kimia. Penambahan pupuk anorganik digunakan karena pelaku usaha belum sepenuhya mempercayai keunggulan pupuk organik dalam meningkatkan produksi. Demikian juga penggunaan pestisida organik masih digunakan terutama untuk membasmi ulat dan siput.

\section{Evaluasi Agribisnis storberi organik di Kabupaen Bolaang Mongondow Timur}

Fokus evalusi adalah pelaku usaha yaitu tempat wisata D'Mooat karena pelaku utama belum melakukan usaha agribisnis. Budidaya tanaman stroberi di tingkat petani telah dimulai sejak tahun 2012 sedangkan di tingkat pemilik wisata D'Mooat mulai dibudidayakan pada tahun 2016. Untuk mengetahui pengembangannya maka dilakukan evaluasi yang dilakukan dengan memodifikasi struktur evaluasi Hammond dalam penelitian ini.

\section{Dimensi Pelaku Agribisnis}

Penanaman stroberi di tingkat petani belum dikembangkan sebagai tanaman komersial karena hanya dibudidayakan di pekarangan rumah, dan sekolah. Hal ini menyebabkan komoditi stroberi belum memberikan tambahan pendapatan untuk keluarga.

Tempat wisata D'Mooat yang menjadi pelaku usaha stroberi, telah membudidayakan tanaman ini sejak tahun 2016 secara komersial. Inovasi terbaru untuk pengembangan teknik produksi dan pengolahan buah stroberi terus dikembangkan. Untuk pengembangan teknik produksi usahatani selalu mencari alternatif terbaik dalam budidaya dan pengolahan produknya. 


\section{Dimensi Aktivitas Agribisnis Stroberi Organik}

\section{a. Aktivitas Agriinput}

Ketersediaan sarana produksi berupa pupuk dan pestisida dalam menunjang teknik produksi di daerah ini belum sepenuhnya tersedia. Ketersediaan berupa pupuk urea, MKP, Boron, KNO3 merah dan putih, perekat, sudah tersedia di Kotamobagu. Demikian juga pestisida berupa toxiput, antracol dan besvidor sudah tersedia. Jika stok yang di Kotamobagu habis, maka pengadaannya diadakan dari Manado. Penggunaan pupuk organik tidak dibuat sendiri namun dipesan secara online berupa hatake dan amway. Sebaliknya untuk pengendalian hama berupa siput dibuat sendiri dengan meracik daun pepaya, tembakau dan bawang putih yang direndam semalaman untuk disiramkan ke media tanam yang terserang.

Kerjasama antar pelaku usaha dan penyedia sarana produksi belum terjalin sehingga pemenuhan kebutuhan dari pelaku usaha disediakan sesuai waktu akan digunakan.

Tenaga kerja yang digunakan dalam usaha tani ini di datangkan dari daerah lokasi penelitian. Khusus yang menangani kegiatan usahatani stroberi tersedia dua tenaga kerja.

\section{b. Aktivitas Agriproduksi}

Tenaga kerja yang digunakan dalam usaha tani ini di datangkan dari daerah lokasi penelitian. Khusus yang menangani kegiatan usahatani stroberi tersedia dua tenaga kerja.

Aktivitas agriproduksi dimulai dari penyiapan media tanam berupa penyediaan polybag untuk ditanami stroberi hingga pemanen buah stroberi.

Media tanam yang digunakan adalah campuran tanah, pupuk kandang, kulit buah kopi, dan sekam bakar. Berat masing-masing polybag $2 \mathrm{~kg}$. Untuk proses produksi maka digunakan pupuk organik seperti hatake dan amway.
Selain penggunaaan organik digunakan juga pupuk an organik pupuk berupa urea untuk merangsang pertumbuhan vegetatif, MKP merangsang pertumbuhan generatif, Boron, KNO3 putih dan merah untuk pertumbuhan vegetatif dan generatif. Dalam penggunaan pupuk daun dicampurkan perekat supaya pupuk yang diaplikasikan tidak tercuci ketika hujan.

Output dari aktivitas agriproduksi menghasilkan produksi buah berkisar antara $720 \mathrm{~kg}$ hingga $1440 \mathrm{~kg}$ atau ratarata sebesar $1080 \mathrm{~kg}$ pertahun. Pendapatan usahatani sebesar Rp 128.505.250 dengan rincian sebagai berikut:

Tabel 1. Biaya, peneriman dan pendapatan Usahatani

\begin{tabular}{lrr}
\multicolumn{2}{c}{ Stroberi } & Tahunan \\
\hline Keterangan & 162.000 .000 & $\begin{array}{r}\text { Bulanan } \\
(\mathbf{R p})\end{array}$ \\
\hline Penerimaan & 14.608 .000 & $1.826 .000 *$ \\
Biaya Persiapan & & \\
Lahan & 6.720 .000 & 840.000 \\
Tenaga Kerja & 7.523 .500 & 940.438 \\
Pupuk & 4.120 .000 & 515.000 \\
Pestisida & 523.250 & 65.406 \\
Penyusutan & 128.505 .250 & 16.063 .156 \\
\hline Pendapatan &
\end{tabular}

Pendapatan pada Tabel 1 adalah pendapatan dalam delapan bulan (stroberi mulai berbuah normal pada bulan ke-4). Dilihat dari rata-rata pendapatan perbulan, maka pendapatan petani stroberi digolongkan sangat tinggi, sehingga komoditi ini apabila dikembangkan dapat membantu petani dalam meningkatkan pendapatan.

\section{c. Aktivitas Agroindustri}

Aktivitas agroindustri adalah pengolahan buah stroberi menjadi juice stroberi, juice stroberi smoothie, dan juice nagaberi. Nilai tambah yang terbesar ditunjukan oleh stroberi smoothie, diikuti oleh juice stroberi dan naga beri. Secara detail nilai perhitungan dengan menggunakan metode Hayami disajikan dalam Tabel 2. 


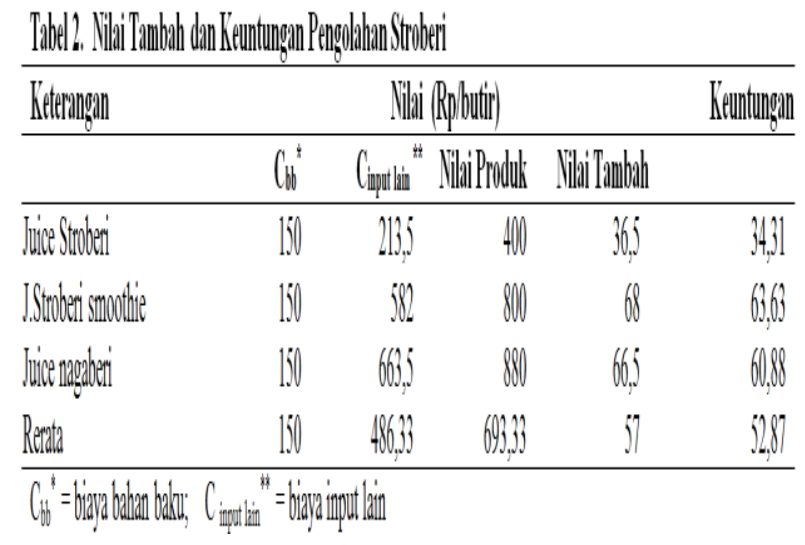

Tabel 2 menunjukkan bahwa Nilai tambah terbesar adalah juice stroberi smoothie yaitu sebesar Rp 68/gram atau Rp 58.000/kg dengan keuntungan sebesar Rp 63,63/gram. Jika melihat dari nilai tambah dan keuntungan maka pengolahan yang memberikan nilai tambah dan keuntungan terbesar pada stroberi smoothie. Namun dii pihak lain, jucie stroberi merupakan juice favorit meskipun memberikan nilai tambah terkecil yaitu sebesar Rp 36,5 (24,3\%). Nilai tersebut memberikan arti bahwa nilai tambah stroberi tergolong tinggi karena melebihi $15 \%$.

d. Aktivitas Agriniaga

Aktivitas agriniaga hanya berlangsung di tempat usaha budidaya stroberi berupa penjualan langsung di tempat produksi. Aktivitas agriniaga berupa penjualan buah stroberi, juice, juga penjualan bibit. Harga bibit Rp 20.000/ polybag. Harga penjualan buah stroberi Rp 150.000/kg, Juice stroberi dan stroberi smoothie seharga Rp 20.000/gelas sedangkan juice nagaberi seharga $\mathrm{Rp}$ 22.000 .

\section{e. Aktivitas Agriservis}

Aktivitas agriservis sudah ada berupa bantuan modal dari perbankan dan dari panah merah dalam konsultasi teknik produksi. Dari pihak pemerintah belum ada kerjasama baik untuk transfer tekonologi produksi berupa penyuluhan dan pengadaan sarana produksi.

\section{Dimensi Perilaku Agribisnis Stroberi Organik}

a. Perilaku Teknik produksi

Perilaku teknik produksi dari pelaku agribisnis tergolong baik karena intensitas kegiatan usahatani hingga pengolahan hasil tergolong tinggi. Teknik produksi budidaya berupa penggunanaa pupuk organik dan pupuk non-organik. Demikian juga pestisida masih bercmpur antara penggunaan pestisida organik dan nonorganik. Hal ini dilakukan dengan intensifnya untuk mendapatkan produksi yang tinggi.

Teknik pengolahan hasil juga dilakukan beupa untuk pengolahan buah stroberi berupa Juice stroberi, Juice stroberi naga, Juice smoothie stroberi. Saat ini pelaku usaha mulai merintis pengolahan stroberi menjadi pisang stroberi sale yang diharapkan dapat menjadi buah tangan D'Mooat.

\section{b. Perilaku manjemen agribisnis}

Perilaku manajemen agribisnis menggunakan sistem manajemen keluarga. Manajemen usahatani dan manajemen keuangan dikelola oleh Ibu sedangkan manajemen produksi dan manajemen pemasaran dikelola oleh anak.

\section{c. Perilaku sistem agribisnis}

Perilaku sistem agribisnis belum terjalin kerjasama antar subsitem agriinput dengan agriproduksi. Pengadaan kebutuhan pada sistem agroproduksi ketersediaanya belum ada kerjasama dalam bentuk kontrak. Kebutuhan agriinput dipenuhi dengan membeli di toko sarana produksi yang ada di Kotamobagu dan Manado. Jika kebutuhan tidak tersedia di dua lokasi ini dipesan lewat media online. Subsistem agriproduksi menyediakan bahan baku untuk agroindustri. Bentuk hubungan yang tercipta adalah hubungan langsung, karena yang mengelola usahatani adalah ibu dan pengelola agroindustri adalah anak dan lokasi dalam satu hamparan yaitu daerah wisata D’Mooat. 


\section{KESIMPULAN DAN SARAN}

\section{Kesimpulan}

1. Pelaku agribisnis di Bolaang Mongondow Timur terdiri dari petani dan pengelola wisata D'Mooat. Di tingkat petani, stroberi belum dijadikan sebagai komoditi komersial namun hanya sebagai tanaman hias. Sebaliknya pengelola wisata sudah menjadikan stroberi sebagai usaha agribisnis.

2. Aktivitas subsistem agriinput berupa penyediaan kebutuhan tenaga kerja yang berasal dari daerah sekitar daerah wisata D'Mooat sedangkan pupuk dan pestisida diperoleh dari Kotamobagu, dan Manado. Aktivitas agriproduksi menghasilkan produksi rata-rata $1080 \mathrm{~kg} /$ tahun pada luasan $2000 \mathrm{~m} 2$, dengan pendapatan jika dijual dalam bentuk segar memberikan pendapatan Rp 128.505.250 /tahun. Aktivitas agroindustri berupa pengolahan buah stroberi menjadi juice stroberi, juice stroberi smoothie, juice nagaberi memberikan nilai tambah rata-rata sebesar Rp.57.000/kg atau keuntungan Rp.52.870/kg. Aktivitas agriniaganya hanya berlangsung di tempat wisata. Aktivitas agriservis berupa bantuan modal dari pihak perbankan.

3. Manajemen perilaku agribisnis untuk manajemen teknik produksi masih menggunakan input agrokimia belum sepenuhnya menerapkan pertanian organik, sedangkan perilaku manajemen agribisnis masih menggunakan manajemen keluarga dan perilaku sistemnya belum optimal pada subsistem agriinput dan agriservis.

\section{Saran}

1. Pihak pelaku usaha wisata D'Mooat mengadakan kerjasama dengan petani sekitar untuk pengadaan bahan baku stroberi dengan menerapkan pola kerjasama bapak angkat. Hal ini dilakukan untuk mengatasi keterbatasan produksi dari lahan dan produksi sehingga permintaan wisatawan sebagai konsumen selalu dapat terpenuhi.

2. Inovasi dalam teknik produksi organik perlu ditingkatkan sehingga tidak lagi menggunakan input agrokimia. Pelaku usaha merupakan pelaku yang kreatif dan penuh inovasi sehingga untuk itu pengembangan penerapan pertanian organik perlu ditingkatkan dengan bekerjasama dengan perguruan tinggi dan pemerintah dalam pembuatan pupuk dan pestisida organik. Peningkatan pendapatan usahatani dan usaha pengolahan produksi masih dapat ditingkatkan dengan berinovasi produk olahan yang lebih tahan lahan sehingga dapat menjadi buah tangan D'Mooat.

3. Peningkatan pendapatan dapat dilakukan oleh pelaku usaha dengan meningkatkan pengelolaannya dari tempat wisata menjadi tempat agroeduwisata yang merupakan perpaduan tempat wisata dan tempat pembelajaran pengunjung dalam pengetahuan tentang pertanian organik dan budidaya, pengolahan stroberi.

4. Menjalin kerjasama dengan travel daerah maupun nasionalat sebagai tujuan wisata alam, pertanian, dan pelatihan pertanian organik.

\section{DAFTAR PUSTAKA}

Hammond R. L. 1967. Evaluation at Local Level. Project Epic. Arizon.

Kodobik, A.E.Loho, J. Dumais, 2017. Pemasaran Stroberi dari Kelurahan Rurukan dan Rurukan Satu. Jurnal Agrisosioekonomi Vol. 13 2A tahun 2017.

Loho A. E. dan R. M. Kumaat, 2016. Strategi Pengembangan Agrowisata Stroberi Organik di Kota Tomohon. Prosiding Seminar Nasional. Pengembangan Pertanian Berkelanjutan yang Adaptif terhadap Perubahan Iklim Menuju Ketahanan Pangan dan Energi. Mataram: UNRAM. 
Offayana Gusti Made, I Wayan Widyantara, I Gusti Ayu Ales Anggreni . 2016. Analisis Resiko Produksi Stroberi pada UD Agro Mandiri di Desa Pancasari Kecamatan Sukasada Kabupaten Buleleng. E-Jurnal Agribisnis dan Agrowisata Vol. 5 No.1 Januari 2016.

Purnomo F. S. 2008. Strategi Pengembangan Stroberi di Kabupaten Purbalingga. Skripsi. Fakultas pertanian UNS Surakarta.

Rukmana H. R. 1998. Stroberi. Budidaya dan Pascapanen. Kanisius. Yogyakarta.
Senewe R., A.E.Loho, M.F.L. Sondakh. 2017. Faktor Penunjang dan Penghambat Usahatani Stroberi di Kelurahan Rurukan dan Rurukan Satu, kota Tomohon kecamatan Tomohon Timur. Jurnal Agrisosioekonomi Vol 13 No. 1A Tahun 2017.

Tangkulung C. M.. 2015. Analisis Kepuasan Konsumen terhadap atribut sayuran organik di Hypermat Manado. Skripsi. Fakultas Pertanian UNSRAT Manado.

Wuner M. B., 2015. Kajian Usahatani stroberi Kelurahan Rurukan Tomohon Timur Kota Tomohon. Skripsi. Fakultas Pertanian UNSRAT Manado. 